\title{
Article Delivery Service
}

Our abstracting service is intended to provide the flavour of the best and most relevant articles we have found in contemporary publications. This is no substitute for reading the original, where it is relevant to your concerns, therefore:

The IDM Knowledge Centre can deliver, by post or fax, a copy of most of the articles abstracted, this service is FREE to IDM members; non-members pay a handling fee of $£ 15$ per article with a maximum handling fee for any one order of $£ 60$.

The law in the UK requires that you sign a copyright declaration before copies can be despatched:

- If the article is for non-commercial research or for private study, no copyright fee is payable, but you may only have one article from each lettered group below.

- If the article is for a commercial purpose the appropriate copyright fee must be paid - fees are given next to the abstract number below.

- For help in deciding whether your purpose is commercial or non-commercial, please contact the IDM Knowledge Centre, or look at the guidance provided by the British Library at www.bl.uk/ services/information/copyrightfaq.html

\section{To order}

When you know whether your purpose is commercial or not, ask the Knowledge Centre to e-mail, fax or post you the appropriate order form.

\section{Contacting the IDM Knowledge Centre}

Telephone: +44 (0) 2086140253

E-mail: knowledgecentre@theidm.com

Post: $\quad$ Knowledge Centre, IDM, 1 Park Road, Teddington TW11 0AR, UK

The Knowledge Centre is staffed on Mondays and Tuesdays by Penny Crossland and on Wednesdays to Fridays by Anita Littler.

\section{Copyright Fees and Lettered Groups}

All fees are subject to VAT at $17.5 \%$.

\begin{tabular}{|lll|lll|lll|lll|lll|}
\hline $\mathbf{7 3 0 1}$ & $£ 25$ & $\mathrm{~A}$ & $\mathbf{7 3 0 6}$ & $£ 25$ & $\mathrm{D}$ & $\mathbf{7 3 1 1}$ & $£ 17$ & $\mathrm{~F}$ & $\mathbf{7 3 1 6}$ & $£ 5$ & $\mathrm{~K}$ & $\mathbf{7 3 2 1}$ & $£ 5$ & $\mathrm{~K}$ \\
$\mathbf{7 3 0 2}$ & $£ 25$ & $\mathrm{~A}$ & $\mathbf{7 3 0 7}$ & $£ 25$ & $\mathrm{~A}$ & $\mathbf{7 3 1 2}$ & $£ 5$ & $\mathrm{G}$ & $\mathbf{7 3 1 7}$ & $£ 13$ & $\mathrm{~L}$ & $\mathbf{7 3 2 2}$ & $£ \mathrm{~V}$ & $\mathrm{~B}$ \\
$\mathbf{7 3 0 3}$ & $£ 25$ & $\mathrm{~A}$ & $\mathbf{7 3 0 8}$ & $£ 25$ & $\mathrm{C}$ & $\mathbf{7 3 1 3}$ & $£ 25$ & $\mathrm{C}$ & $\mathbf{7 3 1 8}$ & $£ 13$ & $\mathrm{M}$ & $\mathbf{7 3 2 3}$ & $£ \mathrm{~V}$ & $\mathrm{~J}$ \\
$\mathbf{7 3 0 4}$ & $£ \mathrm{~V}$ & $\mathrm{~B}$ & $\mathbf{7 3 0 9}$ & $£ 25$ & $\mathrm{C}$ & $\mathbf{7 3 1 4}$ & $£ 25$ & $\mathrm{H}$ & $\mathbf{7 3 1 9}$ & $£ 25$ & $\mathrm{~N}$ & $\mathbf{7 3 2 4}$ & $£ 25$ & $\mathrm{~A}$ \\
$\mathbf{7 3 0 5}$ & $£ 25$ & $\mathrm{C}$ & $\mathbf{7 3 1 0}$ & $£ 17$ & $\mathrm{E}$ & $\mathbf{7 3 1 5}$ & $£ \mathrm{~V}$ & $\mathrm{~J}$ & $\mathbf{7 3 2 0}$ & $£ 25$ & $\mathrm{P}$ & & & \\
\hline
\end{tabular}

$\mathfrak{E V}$ means a photocopy for commercial purpose is not available but visitors may read the article in the Knowledge Centre (by appointment, please).

n/a means a photocopy is not available but visitors may read the article in the Knowledge Centre (by appointment, please). 
The bold items in the margin describe the subject matter and are keywords for text retrieval. The final reference number under each abstract is also used for this purpose (see reprint service on $p$ 270)

\section{Abstracts}

Each abstracted article is awarded $0-5$ stars for each of four qualities:

(1) depth of research

(2) value in practice

(3) originality of thinking

(4) readability for non-specialists.

No abstract is included for any article awarded less than seven stars overall.

\section{Managing customer profitability using portfolio matrices}

\section{Ang and B. Taylor}

CASE STUDY. Journal of Database Marketing \& Customer Strategy

Management (UK), Vol. 12, No. 4, p. 298 (6pp)

Notes the abundance of literature on managing customer relationships, and the dearth on managing profitable customers. Traces the growth in B2B studies of customer portfolio analysis, but still with little reference to profitability. Reports the results of a study of 130,000 B2C customers of an internet ISP, taking into consideration two customer dimensions: the gross margin of each customer (ie revenue from fees less network costs and costs to service), and length of tenure. Combination of these dimensions gave four cells of low- and high-tenure customers, each divided into high and low gross margin. Describes the outcome as a customer profitability mapping (CPM) model. Seeks to answer whether some (particularly loyal) customers are more profitable than others; whether changing modes of communication to different groups influences behaviour; whether this will enhance total company gross margin. Gives results of study: as at June 2003, 44 per cent of customers contributed to gross margin, 33 per cent having high tenure and 11 per cent low tenure; 14 per cent had low tenure and low margin, with 10 per cent being negative margin; 42 per cent had high tenure and low margin, with 20 per cent negative. Details the different subsequent treatment given to each group, and the beneficial results that followed, including an uplift of 2.4 per cent in company gross margin. Ends with warning that findings may not be generalisable beyond services such as mobile phones and internet services which are susceptible to customer churn.

Ignore the tedious first two pages of literature review, and read this as a case study of some interest. But never forget that today's low (or negative) gross margin customers may be tomorrow's stars.

Research: $* * *$ Practice: $* * *$ Originality: $* * *$ Readability: $* * *$ Ref: 7301 
CRM, data quality, data cleansing, data integration
CRM, technology, CLV

\section{Invisible data quality issues in a CRM implementation}

A. Reid and M. Caterall

CASE STUDY. Journal of Database Marketing \& Customer Strategy

Management (UK), Vol. 12, No. 4, p. 305 (11pp)

Notes the lack of attention in the literature to data quality problems, despite their prevalence in much CRM implementation. Quotes an estimate that poor data quality costs US businesses $\$ 611 \mathrm{~m}$ per year, with only 33 per cent of concerns being confident of their data quality. Lists five sources of poor data: erroneous data entry; missing data; lack of coding standards; legacy data from different incompatible systems; older systems with poorly documented/obsolete data. Considers data cleansing, but emphasises need for ongoing metrics to maintain cleanliness thereafter. Notes that while a good data-entry clerk makes 2-4 per cent errors, self-submitted data on the web contains $10-15$ per cent error. Looks at these problems in the context of a large European telecommunications company which has been implementing CRM projects since the late 1990 s. Notes the quality problems encountered in migrating data to a central database; the impact of new quality requirements on the performance measurement and rewards systems of call centre staff; the need for data validation on self-service channels (and its cost); the problems of name and address matching; the difficulty of obtaining senior management commitment, and budgetary priority, for data quality. States the need for a 'data governor'. Emphasises the need for attention to questions of data ownership.

The range of problems associated with data integration is well described - particularly the gross failure of companies to anticipate the occurrence or likely costs of curing, or living with, such problems. One would like, however, a bit more attention to the nitty-gritty of how these problems were tackled by the company being studied.

Research: $* * \quad$ Practice: $* * * *$ Originality: $* * \quad$ Readability: $* * *$ Ref: 7302

\section{Strategy, technology and organisational alignment: Key components of CRM success}

M. L. Roberts, R. R. Liu and K. Hazard

THEORETICAL. Journal of Database Marketing \& Customer Strategy

Management (UK), Vol. 12, No. 4, p. 315 (12pp)

Considers the role of technology in the success or failure of CRM projects.

Holds that strategy, technology and organisational alignment are all important. Outlines a number of steps to successful CRM implementation, and discusses each: developing a customer strategy (including the use of customer lifetime value to distinguish profitable from unprofitable customers); setting customer objectives; ensuring organisational readiness (including executive commitment to the project); aligning the enterprise behind corporate CRM goals (including the creation of a powerful guiding coalition); executing CRM programmes (including focusing on specific customer value segments); and measuring programme effectiveness (gives 
examples of metrics suitable for different functions within the enterprise). Emphasises that CRM is a long-term process of organisational change and development; that technology (eg the development of a powerful database) is a necessary but not sufficient component of success; that it is essential to create a customer-focused organisation before thinking of installing CRM technology. Ends with a short case study.

Sound common sense delivered in a somewhat dry academic style; worth reading.

Research: $* * \quad$ Practice: $* * * *$ Originality: $* \quad$ Readability: $* * *$

Ref: 7303

\section{National Trust, CRM}

\author{
Analytics, \\ segmentation, CRM
}

\section{National Trust out of the woods \\ D. Nordberg}

CASE STUDY. Market Leader (UK), Spring 2005, p. 56 (3pp)

Notes recent improvement in the affairs of the National Trust - revenues up by 50 per cent; membership up by one-third; customer satisfaction up by 10 per cent. Traces this improvement back to changes made in the dark days of 2001 ( $m a d$ cows, foot-and-mouth, recession, 9/11) and the appointment of new management dedicated to producing a database equipped for CRM. Notes early warfare within the Trust between those providing for visitors and conservationists - this conflict now replaced by cross-functional teamwork - and the previous lack of hard-edged commercial thinking. Describes new concentration on the 'customer journey' - through the duration of each visit and over a lifetime catering separately for each group of visitors and members at every stage.

The National Trust is a good model to study, since its remit and activities are widely understood, and its problems readily grasped.

Research: * Practice: $* * \quad$ Originality: $* \quad$ Readability: $* * *$ Ref: 7304

\section{Making customer analytics work for you!}

A. Marsella, M. Stone and M. Banks

OPINION PIECE. Journal of Targeting, Measurement and Analysis for

Marketing (UK), Vol. 13, No. 4, p. 299 (5pp)

Hails the decline of pure batch-based segmentation using historic data, claiming this results too often in customers receiving the wrong offer at the wrong time with the wrong creative through the wrong channel. Welcomes instead the advent of real-time analytics, using only data supplied during the current transaction, which works well for simple products; approves the linkage of prior batch analysis with real-time analysis in more complex areas. Emphasises the importance, in many relationships, of permission and trust: holds that nothing destroys these so quickly as irrelevance - eg a bank offering a loan to a client with a large deposit. Posits the necessity of having a sound CRM platform across all channels; notes that advanced CRM systems contain the latest analytics packages. Illustrates with two brief case studies (British Columbia Automobile Association and Cathay Pacific). Emphasises that staff must 
Mobile phones, banking, 3G, Meridea, CRM

\section{Mobile services}

be empowered to sell what the customer wants to buy, not what the product manager wants to sell; target setting, incentives and success measures must all be revised to focus on successful lifetime management of the customer experience.

A reasonable (if perhaps optimistic) view of how the marketplace is changing. The exhortations are unimpeachable, but there is a distinct lack of nitty-gritty how-to-do-it.

Research: $* \quad$ Practice: $* * \quad$ Originality: $* \quad$ Readability: $* * *$ Ref: 7305

\section{Mobile banking: A powerful new marketing and CRM tool for financial services companies all over Europe}

J. Riivari

SURVEY. Journal of Financial Services Marketing (UK), Vol. 10, No. 1, p. 11 (10pp)

Claims 6 million persons in Western Europe now use banking services by mobile phone; there are three times as many mobile phone users as online PCs. Indicates important developments are the arrival of $3 \mathrm{G}$ standards, together with secure Java-based software such as Meridea Smart Client; half of all mobile phones are Java enabled now, and most will be within 18 months. Meridea, unlike WAP banking, allows users to work offline with only brief online connection for transmission, keeping banks' and users' costs down. Claims a bank's cost in handling a mobile transaction is only 10 per cent of its cost for a contact centre call. Describes some services that banks can offer to mobile users: a pre-installed quick loan calculator giving an instant tailored product; a simulator to allow calculation of accumulation of savings or pension rights. Expects the installation by banks of mobile CRM systems in 2006. Looks in turn at mobile banking in a number of European countries: France has 39 per cent of all Western European mobile banking customers; in the UK the market is led by First Direct, with one new customer in eight saying mobile banking was the deciding factor in changing to this bank. Looks briefly at the situation in Eastern Europe, and in Asia.

As with many articles hailing new trends in the marketplace, the style is somewhat overexcitable, and there is confusion in the tables, some of whose figures do not agree. But the trends are real: for once banking is in the forefront of new marketing developments instead of playing catch-up.

Research: $* * \quad$ Practice: $* * \quad$ Originality: $* \quad$ Readability: $* * *$ Ref: 7306

\section{Marketing m-services: Establishing a usage benefit typology related to mobile user characteristics}

G. S. Mort and J. Drennan

SURVEY. Journal of Database Marketing \& Customer Strategy

Management (UK), Vol. 12, No. 4, p. 327 (15pp)

Groups consumers into five categories: innovators; techno-confidents; shopping lovers; belonging-seekers; consulters. Groups available mobile 
services in six categories: locator; communication; sports/entertainment; 'chat'; value-added shopping; financial. Hypothesises about the likely tendency of each group of consumers to use m-services from each of the six mobile categories, and expected gender and age-related differences within each group. Reports on a survey of 250 mobile phone users, comprising university staff and students plus others recruited by these, aged from 17 to $40+$ and with 59 per cent being female to 41 per cent male. Describes the survey. Finds no gender differences, other than a greater male propensity to use sports/entertainment facilities, and no agerelated propensities. Notes a variety of other relationships between each consumer group and each services grouping. Concludes that the product extension market for $\mathrm{m}$-services should build on the established methods used for the mobile handsets themselves: peer bonding, celebrity endorsement, social networking; marketers equipped with database information on consumer characteristics will be well placed in this market.

Few of these findings are at all counter-intuitive - for example the finding that value-added shopping services are attractive to lovers of shopping. Nor is the survey method impressive. Nevertheless, there is some interesting material.

Research: ** Practice: $* * \quad$ Originality: $* \quad$ Readability: $* *$ Ref: 7307

\section{SMS, text messaging, m-commerce}

\section{Text message advertising: Response rates and branding effects}

R. Rettie, U. Grandcolas and B. Deakins

RESEARCH. Journal of Targeting, Measurement and Analysis for

Marketing (UK), Vol. 13, No. 4, p. 304 (9pp)

Notes the slow adoption of internet-based m-commerce in the USA and Europe, but the continuing explosive growth of SMS text messaging and its success as a stand-alone or integrated marketing communications tool. Aims to examine customer response to SMS ads, including branding and purchase intention effects. Quotes mobile marketing revenue expected as $\$ 16-23$ bn worldwide by end 2005, with 78 per cent penetration in the UK in 2003. Notes the intrusiveness of much direct marketing, especially telemarketing, and the curse of spam in e-mail marketing. Indicates advantages of SMS: advertising relevance adds value and permission reduces intrusiveness. Reports research by telephone into the effectiveness of 26 SMS advertising campaigns, using 200 random recipients of each. Analyses results, as reported by those surveyed, specifically: acceptability, interest and relevance; response (across five different types of action requested); branding effect; effect on purchase intention; creative execution. Notes that while results were overall very positive, they may be exaggerated by being self-reported, but holds that SMS combines the impact of telemarketing, the digitalisation of e-mail and the localisation of m-commerce, with an acceptability of 44 per cent and an average response of 31 per cent. Accepts that proliferation (and spam) may reduce its effects in time. 


\section{Telemarketing, predictive dialling, silent calls, outsourcing, offshore}

Interesting and instructive in itself, although the comparisons with other media are ultimately worthless since every new medium enjoys a honeymoon period until overuse, saturation and misuse dull its impact.

Research: **** Practice: $* *$ Originality: $* *$ Readability: $* * * *$ Ref: 7308

\section{Outbound calling - Discredited or misunderstood?}

R. Grig OPINION PIECE. Journal of Targeting, Measurement and Analysis for Marketing (UK), Vol. 13, No. 4, p. 295 (4pp)

Notes the laborious nature of outbound telemarketing, where manual calling may give an agent no more than 15 minutes talk time per hour. Describes the development of three new technologies to improve labour productivity: progressive dialling and preview dialling (which both leave the agent in control of calls, but remove some of the manual chores and raise potential talk time to 30-35 minutes per hour), and predictive dialling, which, as a by-product, results in 'silent' calls. Reveals that predictive dialling arose in the USA as a technique for debt collectors circumstances in which the effect of silent calls on the consumer was not regarded as important. Notes the migration of this technology to general telemarketing, the consequences for consumers and the arrival in the USA of restrictive legislation - while claiming that so many Americans are now on the do-not-call list that telemarketing in the USA is now all but dead. Notes in detail the DMA's code of practice, which embodies four main rules. Details how these rules are widely (and/or wilfully) misinterpreted or ignored. Notes the illegal use of calls that play recorded messages. Recommends regulation and enforcement by Ofcom, covering also firms that outsource offshore. Holds that it is not (yet) too late for the industry to get its act together.

Illuminating on the background to silent calls, but the view that this irresponsible industry can pull itself back from the brink before, in a few years' time, it self-destructs is surely over-optimistic, as is the suggestion that Ofcom could ever monitor the activities of offshore call centres. And now will e-mail marketing follow telemarketing, for similar reasons, into oblivion?

Research: $* * \quad$ Practice: $* \quad$ Originality:** Readability: $* * * *$ Ref: 7309

\section{The state of interactive marketing in seven countries: Interactive} marketing comes of age

P. Barwise and J. U. Farley

SURVEY. Journal of Interactive Marketing (USA), Vol. 19, No. 3, p. 67 (14pp)

Sets out to answer, from an empirical study, a series of questions about the current condition of interactive marketing (IM) in the USA, Japan, 
Germany, the UK, France, China and Brazil, its rate of past growth and prospects for the future. Concludes that IM is growing faster than any other category of marketing spend, but from a low base (8.3 per cent of total spend projected in 2004, up from 6.5 per cent in 2002 - a growth of 22 per cent in two years); IM is stronger in B2B (10 per cent of marketing spend) than $\mathrm{B} 2 \mathrm{C}$ ( 6 per cent); there is little variation between the seven countries, although France is a laggard in current IM spend, and France and Japan have lower growth forecasts, while the USA and UK are growing very fast. Provides numerous tables to illustrate these points, showing also IM expenditure by industry sector and by products/services, and type of IM activities prevalent in each country, together with a factor analysis showing how these different activities correlate. Notes in particular the growth in SMS marketing. Expects future IM growth to be at the expense of traditional media advertising.

A fascinating survey; the general picture is reasonably well known, but is well quantified here, and there are one or two unexpected twists.

Research: $* * * *$ Practice: $* * \quad$ Originality: $* \quad$ Readability: $* * * * *$ Ref: 7310

\section{Multichannel marketing, integration, channel relationships}

\section{Opportunities and challenges in multichannel marketing}

A. Rangaswamy and G. H. van Bruggen

EXPLORATORY. Journal of Interactive Marketing (USA), Vol. 19, No. 2, p. 12 (19pp)

Distinguishes between traditional multiple channel marketing (where a firm approaches different customers through different channels) and multichannel marketing, where customers use different channels, at their choice, at different times. Identifies a series of six vital questions about multichannel shopping: what are the characteristics of multichannel shoppers; is the strategic aim of multichannel marketing to switch lowvalue customers to low-cost channels, or to provide a greater number of accessible touch-points to all customers or something else; how should employees be organised and incentivised in a multichannel marketing environment; how does multichannel marketing affect channel relationships through actual or potential disintermediation, and how can a common brand experience be delivered to customers across channels and intermediaries; how can marketers assess the relative efficacies of various marketing approaches at different stages in the decision process, when different stages in this process may occur in different channels; how does inconsistency of information across channels (eg on the inventory position) affect customer satisfaction and loyalty. Calls for integrated customer databases, while noting the need for a strategic rationale in database design.

This is an introductory chapter to a special issue on multichannel marketing. It does an excellent job in asking questions which it is hoped subsequent articles will address - perhaps even answer. Unfortunately the subsequent articles are mostly unreadable. But, the right questions are 


\section{Customer satisfaction, employee engagement}

more than half the battle: read this introduction and find your own answers.

Research: * Practice: $* * *$ Originality: *** Readability: $* * * *$ Ref: 7311

Manage your human sigma

J. H. Fleming, C. Coffman and J. K. Harter

MANAGERIAL. Harvard Business Review (USA), July/August 2005, p. 107 (9pp)

Contrasts the problem of managing quality outcomes in a manufacturing context and in the case of an employee-customer encounter. Notes that in the former case measurement criteria are data-driven, rational and analytic; in the latter case they are a complex mixture of emotion and reason - with emotion often dominant. Gives example of a US bank where rationally satisfied customers behave in an identical manner to dissatisfied customers, whereas emotionally satisfied customers perform much better. Claims that most companies measure success (eg in customer satisfaction or employee engagement) centrally, as an average figure, which conceals wide local variations - often much wider than variations among competitors. Reports a study of 1,979 business units in ten companies which showed that those with a high customer engagement or high employee engagement were 70 per cent more effective, while those with high engagement of customers and staff were 100 per cent more effective still. Insists measurement of outcomes must be local, with central responsibility.

An interesting look at customer-employee interaction.

Research: ** Practice: $* * \quad$ Originality: $* * \quad$ Readability: ** Ref: 7312

\section{Sales compensation plans - One size does not fit all}

L. J. Ryals and B. Rogers

REFLECTIVE. Journal of Targeting, Measurement and Analysis for Marketing (UK), Vol. 13, No. 4, p. 354 (9pp)

Considers the state of play in variable pay compensation plans for salespeople in B2B markets; in particular reviews methods for rewarding key account managers. Notes that a high proportion of sales persons' pay is still focused on sales volumes: only 8 per cent of surveyed US companies did not use annual quotas to reward their salespeople. Considers the problems of variable pay: the demotivating effect of high fluctuations in income; competitive pay structures often create more losers than winners; they counteract teamwork; they encourage game playing by sales people, and the adoption of a short-term view. Notes the increasing importance of teamwork in selling, and the need for variable pay systems to be consistent, unbiased, accurate, representative, ethical and seen to be 'fair'. Notes the role of the key account manager, who is 
concerned with long-term relationships and therefore might appropriately have a higher proportion of reward in fixed salary. Suggests that, instead of rewarding all sales persons on the same basis, the reward mechanism should be determined by the type of prospect/customer involved and the degree of skill required to bring about an outcome. Produces a customer portfolio matrix to support this idea.

A useful discussion of the difficult subject of rewards and incentives for salespeople. Omits, however, to note that every incentive system becomes distorted over time by changing circumstances, and should therefore be set up with an avowedly short life.

Research: $* * \quad$ Practice: $* * \quad$ Originality: $* * \quad$ Readability: $* * *$ Ref: 7313

Metrics, norms, training
Metrics, ROI, channels

\section{Marketing metrics: A can of worms or the path to enlightenment? M. Uncles \\ EDITORIAL. Journal of Brand Management (UK), Vol. 12, No. 6, p. 412 (7pp)}

Notes a widespread consensus on the importance of metrics. Suggests this consensus is more apparent than real: there is little agreement on what metrics are, and motives in trumpeting their importance are mixed or confused. Gives definitions of metrics at different levels: measurement of the results of specific activities; product/service-level metrics; metrics linking marketing investment to corporate performance. Lists differing motivations: allocation of marketing resources; to make marketing more accountable; politicking and posturing. Considers the pragmatic use of individual discrete measurements versus the academic leaning towards composite indices. Emphasises the need for metrics to be related to a benchmark or norm, and the need for training to improve marketers' analytical skills and financial literacy as well as accountants' marketing understanding. Advocates codification of existing metrics for different levels and purposes. Notes danger of ignoring what cannot be readily measured - creativity, people skills, etc.

A difficult article to summarise, since it is tightly packed with sound common-sense analysis and prescription, as well as a dose of healthy scepticism at the latest piece of received wisdom.

Research: Practice: $* * * *$ Originality: $* * *$ Readability: $* * * *$ Ref: 7314

\section{How to measure multichannel campaigns}

\section{H. Wilson, L. Bruce and J. Love}

THEORETICAL. Admap (UK), July/August 2005, p. 36 (3pp)

Notes the difficulty inherent in measuring the contribution to ROI of different channels in a multichannel campaign — where a customer who browses your site on the web may also receive a direct mail shot before buying in store. Shows illustrative diagram of customer cross-channel 
Unisys, metrics, dashboard behaviour. Advocates use of control group measurement and econometric modelling. Questions how metrics can be used to control and reward channel performance: instances BT's target setting for its sales managers based on the expense-to-revenue ratio of accounts for which they were responsible - irrespective of channel.

A useful introduction to a topic that needs much more in-depth study. Control group management (a fancy new term for familiar direct mail testing techniques) is explained barely adequately, and econometric modelling not at all. But better than nothing.

Research: $* * \quad$ Practice: $* * \quad$ Originality: $* \quad$ Readability: $* * *$ Ref: 7315

\section{Measuring marketing effectiveness and value: The Unisys marketing dashboard}

A. Miller and J. Cioffi

CASE STUDY. Journal of Advertising Research (UK), Vol. 44, No. 4, p. 237 (7pp)

Notes the growing demand for measuring marketing impact and ROI. Reveals that Unisys marketing is conducted at six levels: global marketing; corporate communications; four business units - as well as in regional marketing groups. Before 2003 there was no single system for evaluating performance, or for aligning it to corporate goals, and no sense of marketing as an investment rather than a cost. Describes the creation of an integrated, online, real-time marketing dashboard system which produces six dashboards - one for each of the above levels - plus an aggregate dashboard with roll-up based on percentage attainment. Describes a three-phase approach to design, development and implementation, starting with seven steps in design common to all dashboards and comprising four corporate goals (financial, customer, employee, reputation), nine marketing goals, 27 objectives and a multiplicity of tactics (campaigns, activities).

The description of the new system and its development reads well - but it does leave one wondering how on earth Unisys's marketing effort, or indeed corporate management, survived for so long without it.

Research: $* * \quad$ Practice: $* * *$ Originality: $* * \quad$ Readability: $* * *$ Ref: 7316

\section{A stakeholder approach to relationship marketing strategy}

A. Payne, D. Ballantyne and M. Christopher

THEORETICAL. European Journal of Marketing (UK), Vol. 39, Nos 7/8, p. 855 (16pp)

Holds that stakeholder theory, though much espoused, has not greatly affected marketing practice to date. Notes a variety of ideas on the appropriate constitution of stakeholder groups. Suggests a relationshipbased approach, emphasising stakeholder collaboration beyond transaction immediacy. Proposes a framework, using the 'six markets' stakeholder model, for analysing stakeholder relationships and planning 
stakeholder strategy. Describes the six markets model: customer markets (active, prospective, intermediaries); referral markets; influencer markets (including shareholders, press, consumer groups); employee markets; supplier markets; internal markets. Reports methods of piloting, testing and working with the model in the UK and Australia: identify key participants in each market; review their expectations and needs; review current and proposed level of emphasis on each market; formulate a relationship strategy for each. Describes each step in detail. Stresses the importance of metrics for each market - eg mutual transaction cost reduction; time to market and quality improvement; staff retention and motivation.

This article is written in academic-speak, which, though irritating, is not unintelligible. If you believe that it is the prime function of business to satisfy (or balance) the needs/wishes of a wide variety of stakeholders a proposition assumed rather than discussed here - then there is interesting material in this article. Or you might wish to debate that premise...

Research: $* * *$ Practice: $* *$ Originality: $* *$ Readability: $* *$ Ref: 7317

\section{Stakeholder theory, DTCA, harm chain}

\section{A model for addressing stakeholders' concerns about direct-to- consumer advertising of prescription medicines}

J. Hoek and N. Maubach

THEORETICAL. European Journal of Marketing (UK), Vol. 39, Nos 9/10, p. $1151(14 \mathrm{pp})$

Starts with a brief review of stakeholder theory; contrasts the view that it is a normative theory setting an ethical framework underpinned by moral values with the view that it is a descriptive theory to enable managers to summarise their personal philosophies, or the instrumental approach that it is a means of enabling organisations to reach their objectives. Considers consensus rests with the normative concept. Discusses how to identify stakeholders and assess the importance of each. Suggests the use of a 'harm chain' approach: identify potential negative consequences of an action; determine those harmed, those who cause harm and those able to address harm. Applies this methodology to direct-to-consumer advertising of prescription medicines (DTCA) as practised in New Zealand. Analyses views (and interests) of opponents and proponents (doctors, consumers, pharmaceutical firms, media, regulators). Suggests means of mitigating conflict between the competing groups.

The discussion of stakeholder theory is important, and well outlined here, though not in great detail. Its application to a fiercely fought struggle over DTCA (which may yet become an issue in Europe and the UK) is instructive.

Research: $* * \quad$ Practice: $* \quad$ Originality: $* * \quad$ Readability: $* * *$ Ref: 7318 


\section{Branding, e- branding, internet}

\section{E-branding strategies of internet companies: Some preliminary insights from the UK}

K. I. N. Ibeh, Ying Luo and K. Dinnie

SURVEY. Journal of Brand Management (UK), Vol. 12, No. 5, p. 355 (19pp)

Indicates two views of branding in the internet era: that the internet undermines branding and leads to a decline in brand appeal; that ebranding is even more essential in an environment of fickle consumers.

Suggests both views may be correct. Aims to examine the importance of e-branding to internet companies; to identify e-branding strategies both online and offline; to explore the international dimensions of e-branding. Describes initial online discussion with seven self-selected individuals, followed by a questionnaire to 80 UK companies (which produced a 19 per cent response), followed by an in-depth study of four of the respondent companies (travel and entertainment; health and beauty with both online and offline presence; stand-alone internet bank; energy supplier). Finds banner ads and online loyalty programmes less effective than registration with main portals, affiliate programmes, word of mouth and viral marketing. Notes the extension of several of the surveyed firms into international e-branding.

Introduces some interesting questions for discussion — but the actual execution is pretty dull.

Research: * Practice: $* *$ Originality: $* * \quad$ Readability: $* *$ Ref: 7319

\section{The complexity of media planning today}

\section{Soberman}

THEORETICAL. Journal of Brand Management (UK), Vol. 13, No. 1, p. 420 (10pp)

Notes the recent rise of 'media expert' or marketing service companies as advisers in the increasingly complex field of the allocation of media spend, offering expertise in linking media habits of consumers to consumption patterns and lifestyles - for B2B as well as B2C. Notes that sellers of media information are often effective monopolies. Notes growth in targeted media vehicles, driven by fragmentation of existing and growth of new media. Shows how tighter targeting of markets (illustrated by reference to the US beer market) can result in reduced competition, particularly over prices: this is one of the very few win-win situations for all competitors. Suggests targeting may actually increase overall advertising spend, by opening the possibility of advertising to previously disenchanted firms. Notes the rise in advertising packages incorporating a wide variety of media in a single deal - eg in sponsorships - and the difficulty in evaluating the value of the component parts in such packages. Emphasises the need for attention to issues of privacy and other ethical concerns.

Linking media habits to consumption patterns and lifestyles is scarcely a 
new idea for direct marketers, but it is always interesting to see the advertising dinosaurs playing catch-up. And some of the points made here, about competition and pricing, are well worth thinking about.

Research: * Practice: $* * \quad$ Originality: *** Readability: *** Ref: 7320

E-commerce, mixed media, advertising

\section{Marketing}

\section{Internet and magazine advertising: Integrated partnerships or not?} A. M. Kanso and R. A. Nelson

SURVEY. Journal of Advertising Research (UK), Vol. 44, No. 4, p. 317 (10pp)

Notes the rapid growth in internet advertising, and provides expenditure figures for e-commerce to 2005. Notes the advantages and limitations of the web as a marketing communications tool. Examines the mixed-media strategy of advertising online and publicising the website address in printed magazines. Looks at six major US magazines with a combined circulation of 21.7 million, and notes the number of advertisements which $\mathrm{did} / \mathrm{did}$ not include a URL. Only 61 per cent did include a URL, many in small print, and few attempted to promote use of the web in the printed advertisement. Considers the extent to which web advertisers used such potential web benefits as company and product information richness; ease of updating; collection of detailed data; global accessibility; customisation of advertisement; enhancement of company-customer relations; role playing; facilitation of purchase. Comments on each. Recommends much closer cooperation between web and print advertisement designers in each company.

A useful look at the phenomenon of poorly designed websites and poorly integrated advertising campaigns - a subject needing much deeper analysis and much more exposure.

Research: $* * *$ Practice: $* * *$ Originality: $* * \quad$ Readability: $* * *$ Ref: 7321

\section{If only for our own sakes, let's take pity on the cowering consumer} J. Bullmore JoURNALISTIC. Market Leader (UK), Spring 2005, p. 14 (2pp) Comments unfavourably on the current vogue for 'aggression' in marketing - which 'seeps out of marketing documents and into marketing communications'. Suggests that the greater the marketer's problems, the greater the need for sensitivity and gentleness. Decries telemarketing - 'a horrible warning to us all' — which threatens marketing's reputation and diminishes brands. Notes the expected largescale advent of automatic commercial-skipping devices, and claims that the answer is not more aggression but a search for relevance to and a respect for the consumer.

If Jeremy would consent to write at greater length and depth, without 

Google, search,
advertising

\section{Surveys, internet}

losing that lightness of touch, then we would have some real marketing literature. Even in this short space, he is worth attending to.

Research: — Practice: $* * *$ Originality: $* *$ Readability: $* * * * *$ Ref: 7322

\section{The search for a new media model: It might be search J. Mandese}

JOURNALISTIC. Admap (UK), July/August 2005, p. 12 (1p)

Notes that Google's market capitalisation is greater than Time Warner's, GM's or China's GNP. Also the collapse of the TV upfront sales market. Asks if this is just the dot.com boom all over again, but suggests that it is really the death of the old advertising model, and wonders what will replace it - individually crafted and targeted marketing messages? Suggests paid search, as pioneered by Google, may be the first form of a new model; notes that the cost of buying keywords on search engines is 'going through the roof' because they deliver customers who are actually in the market and prepared to buy.

The death of traditional media advertising (especially on TV) is much prophesied, but, as I tried to watch cricket on Channel 4 last summer, it clearly had not happened by then. No doubt in time it will.

Research: *** Practice: $* *$ Originality: $*$ Readability: $* * * *$ Ref: 7323

\section{Do internet-based surveys increase personal self-disclosure?}

R. C. Hanna, B. Weinberg, R. P. Dant and P. D. Berger SURVEY. Journal of Database Marketing \& Customer Strategy Management (UK), Vol. 12, No. 4, p. 342 (15pp)

Notes the rise in recent years in the use of internet-based surveys by both academics and practitioners. Notes concern among users over response quality and level of self-disclosure. Considers relative costs of internetbased and mail surveys: the former are 30-60 per cent cheaper, not including cost of time and data entry for mail surveys. Notes other internet-based advantages: flexibility of design; greater speed of response. Reports little difference in response rates. Points to the difficulty with internet-based surveys of securing a random sample of a desired population. Notes difficulties over self-selection bias and respondent authenticity - but suggests these are no different for either medium and the need to guard against multiple responses. Reports a study of 178 undergraduates at a US university designed to reveal relative sense of private and public self-consciousness when completing an anonymous or non-anonymous survey either internet-based or paper-based. Reports that responders to internet-based surveys are more self-aware and thoughtful, and thus more likely to reveal deeper feelings.

The first two pages have interesting and comprehensive things to say about internet-based surveys; the remaining 12 pages are a dry, academic 
Abstracts

consideration of some pretty abstract concepts whose practical application may be thought rather negligible.

Research: $* * *$ Practice: $* *$ Originality: $* *$ Readability: $* *$ Ref: 7324 